\title{
Bacteriological Studies on Flavobacterium columnare in Fish
}

\author{
I.M. Eid *, M.E. Abou ELAtta **, N.H. Eidaroos *, N.I. Farg Allah \\ "Bacteriology, Immunology and Mycology Department, Fac. Vet. Med. Suez \\ Canal University. " Central Laboratory for Aquaculture Research. Abbassa, \\ Abou Hammad, Sharkia
}

\begin{abstract}
Columnaris is one of the oldest known fish diseases caused by Flavobacterium columnare. The wide spreading of the causative agent in freshwater environments and the susceptibility of fish to be attacked by it after mechanical and/or environmental factors makes $F$. columnare among the most prevalent pathogens in cultured, ornamental, and wild fish populations. One hundred fishes of tilapia (Oreochromis niloticus) were collected randomly from ponds of Central Laboratory for Aquaculture Research of Abbassa, Abou Hammad, Sharkia, Egypt for Flavobacterium columnare isolation. F. columnare was isolated from (150) out of the (350) examined samples. The bacteriological examination revealed that the prevalence of $F$. columnare was $(42.8 \%)$ in Oreochromis niloticus. The highest prevalence of $F$ columnare was in gills $(33.3 \%)$ followed by skin (30\%) then fins $(24.6 \%)$ and kidney (12\%). These isolates were further characterized by PCR that revealed positive result for $16 \mathrm{~S}$ RNA gene with specific amplicons size $675 \mathrm{bp}$. The result of antimicrobial sensitivity testing of the isolates revealed that doxycycline, erythromycin, tetracycline, trimethoprim, nalidixic acid and streptomycin were the most effective drugs against $F$.columnare.
\end{abstract}

\section{Introduction}

Flavobacterium columnare is thin, Gram-negative, rod-shaped bacteria discreted from the other comparable bacteria in morphology by their distinctive rhizoid pattern of growth on a low nutrient medium, and by their growing ability on media containing neomycin and polymyxin B. Griffin (1992).

Columnaris disease considers the second leading killer of commercially raised channel catfish, Ictalurus punctatus next to enteric septicemia (ES) caused by Edwardsiella ictaluri.Durborow et al. (1998)

Columnaris disease or mixed infections of columnaris and ES were listed as the first cause of the greatest economic losses on catfish farms by $70 \%$ of farmers from the four leading catfish producing states (USDA, 2003), with losses estimated in the millions of dollars. This study aimed to investigate the propagation of Flavobacterium columnare in Oreochromis 
niloticus,

characterize

representative $F$. columnare isolates recovered from Oreochromis niloticus and summarize the resistance pattern of isolated $F$. columnare against various antibiotics.

\section{Material and Method:}

Fish:

Total number of (100) clinically diseased tilapia fish of the genus Oreochromis niloticus were transferred alive in oxygenated plastic containers to the laboratory and subjected to full clinical and postmortem examination.

\section{Bacteriological examination:}

Samples were taken under complete aseptic conditions from gills, skin, fins, kidney, liver, spleen and muscle. The samples were inoculated onto Ordal's broth for 28 hrs at $37^{\circ} \mathrm{C}$ then subcultured on Ordal's agar. The obtained pure colonies were identified according to colonial morphology, slide film was stained with gram stain for microscopical examination and description of the shape and arrangement of bacteria was done according to Collins et al; (1989).

Polymerase Chain reaction:

For accurate identification of Flavobacterium columnare universal primers for 16S rRNA gene were used Table (1). DNA extraction had been done by following manufacturer's instructions of QIAamp DNA mini kit. PCR products were electrophorized using 1\% Agarose gel using Gel casting apparatus (Biometra). The gel was photographed by a gel documentation system and the data analyzed through computer software according to Sambrook et al. (1989).

\section{Antimicrobial sensitivity test:}

The antimicrobial sensitivity test of $F$. columnare isolates were performed by disc diffusion test according to Bauer et al. (1966) and interpreted according to NCCLS/CLSI (2007).

Table (1) Oligonucleotide primers sequences:

\begin{tabular}{|c|c|c|c|}
\hline \multirow{2}{*}{ Primer } & Sequence & $\begin{array}{c}\text { Amplified } \\
\text { product }\end{array}$ & \multicolumn{2}{c|}{ Reference } \\
\hline $\begin{array}{c}\text { F.COLUMNARE } \\
\text { 16SrRNA }\end{array}$ & F: 5`-CAGTGGTGAAATCTGGT-3` & 675 & $\begin{array}{l}\text { Darwish } \\
\text { al., 2004 }\end{array}$ \\
\cline { 2 - 2 } & R: 3`-GCTCCTACTTGCGTAGT-5` & 675 \\
\hline
\end{tabular}

\section{Results and Discussion:} clinical examination of fish: Naturally infected Oreochromis niloticus were clinically examined and revealed loss of scales with presence of grey-white discoloration on some parts of the head, tail, around the mouth, fins and other areas (Figure 1). In some cases, ulceration, and degeneration of underlying muscle fibers around dorsal fin observed (saddle back lesion) (Figure 2). The gill filaments showed presence of 
congestion, necrosis and covered with excessive mucus.

\section{Bacterial isolation and identification:}

The present study revealed that $F$. columnare can grow only on the selective media (cytophaga agar media) with addition of antimicrobial agents including polymyxin B and neomycin sulfate in order to inhibit growth of other bacteria. Colonies appeared on selective media as smooth flat golden yellow colonies with circular edges measuring 3-4mm in diameter and adhered to the agar. Microscopically, isolates were gram-negative bacterium, long rods and scattered in arrangement. This result was harmonious with those recorded by Bullock et al., (1986), Griffin (1992) who stated that selective media must be used to isolate $F$. columnare and differentiate it from other yellow pigmented gliding bacteria. They described the colony on solid media as yellow to orang in color, translucent, circular, smooth and shiny with entire edges.

The present investigation revealed that the total prevalence of $F$. columnare among naturally infected Oreochromis niloticus was $(42.8 \%)$ Table( 1),this finding was higher than recorded by Elgamal (1995) who recorded that prevalence of $F$. columnare among naturally infected tilapia was (16.6\%).also higher than result obtained by Eltalaway (2008) who found that that prevalence of $F$. columnare infection in examined
Clarias guriepinus was (22.9\%) and Kamel (2013) who recorded (4.16\%)among infected Oreochromis niloticus.

The isolation of $F$. columnare occurred from gill with the highest prevalence (33.3\%) followed by skin $(30 \%)$, tail and fins $(24.6 \%)$ and kidney $(12 \%)$ while, there is no isolation found from other internal organs Table (2). This agree with that stated by smith (1982) who mentioned that the gill is the largest tissue for presence of $F$. columnare, Elgamal, (1995) and Eltalaway (2008) who isolated $F$. columnare from skin, gill and kidney.

\section{Genotypic characterization:}

The molecular identification of $F$. columnare byPCR produced unique and clear bands corresponded to the 675 base pair (bp) by internal fragments of $16 \mathrm{~S}$ rRNA gene confirmed without doubt that the isolated strains were $F$. columnare (Figure 3). These results were similar to those was recorded by Darwish et al., (2004).

\section{Antibiotic sensitivity test:}

The present findings showed that $F$. columnare strains were sensitive to tetracycline, nalidixic acid, trimethoprim, doxycycline, streptomycin and erythromycin. While moderately sensitive to colistine and kanamycin and highly resistant to neomycin, Table (3). These result is assents with Hesami et al. (2010) who recorded that all strains of F.columnare were susceptible to ampicillin, erythromycin, streptomycin, 
tetracycline, trimethoprim- sulphat but displayed acquired resistance to neomycin and polymyxin B. and partially agree with the result recorded by Elgamal (1995) and Varga et al. (2016).

On conclusion, this study indicated that $F$. columnare is one of the most common fish pathogens which cause mortalities and high economic losses. High prevalence of F. columnare among Oreochromis niloticus collected from ponds of Central Laboratory for Aquaculture Research of Abbassa, Abou Hammad, Sharkia, Egypt reaches to (42.8\%). The distribution of organism in tissue and organs of infected Oreochromis niloticus were high in gills (33.3\%) followed by skin $(30 \%)$ then fins $(24.6 \%)$ and kidney (12\%). Nalidixic acid, tetracycline, streptomycin, erythromycin, doxycycline and trimethoprim were the most effective drugs against $F$. columnare.

Table (1): Prevalence of F.columnare in examined Oreochromis niloticus

\begin{tabular}{|c|c|c|c|c|}
\hline Fish species & Total No & Total samples & $\begin{array}{c}\text { Positive growth } \\
\text { samples }\end{array}$ & $\begin{array}{c}\text { \%of } \\
\text { isolation of } \\
\text { F.columnare }\end{array}$ \\
\hline $\begin{array}{c}\text { Oreochromis } \\
\text { Niloticus }\end{array}$ & 100 & 350 & 150 & $42.8 \%$ \\
\hline
\end{tabular}

Table (2) Prevalence of F.columnare among various organs of Oreochromis niloticus samples.

\begin{tabular}{|c|c|c|c|c|c|c|c|c|c|c|c|c|c|c|c|}
\hline \multirow{3}{*}{ Bacteria } & \multirow{3}{*}{$\begin{array}{l}\frac{\overrightarrow{0}}{\grave{D}} \\
z \\
z\end{array}$} & \multicolumn{14}{|c|}{ Organ } \\
\hline & & \multicolumn{2}{|c|}{ gill } & \multicolumn{2}{|c|}{ skin } & \multicolumn{2}{|c|}{ Tail\&fin } & \multicolumn{2}{|c|}{ kidney } & \multicolumn{2}{|c|}{ liver } & \multicolumn{2}{|c|}{ spleen } & \multicolumn{2}{|c|}{ muscle } \\
\hline & & No & $\%$ & No & $\%$ & No & $\%$ & No & $\%$ & No & $\%$ & No & $\%$ & No & $\%$ \\
\hline F.Columnare & 150 & 50 & 33.3 & 45 & 30 & 37 & 24.6 & 18 & 12 & 0 & 0 & 0 & 0 & 0 & 0 \\
\hline
\end{tabular}

Table (3) Results of antibiotic sensitivity test of isolated bacteria

\begin{tabular}{|c|c|c|c|}
\hline \multirow{2}{*}{ Antibiotic agent } & Disc conc & \multicolumn{2}{|c|}{ F.columnare } \\
\cline { 3 - 4 } & $(\mu \mathrm{g})$ & Inhibition zoon $(\mathrm{mm})$ & Reaction \\
\hline Colistine sulfate & 10 & 7 & $\mathrm{I}$ \\
\hline Streptomycin & 10 & 23 & $\mathrm{~S}$ \\
\hline Kanamycin & 30 & 17 & $\mathrm{I}$ \\
\hline Erythromycin & 15 & 23 & $\mathrm{~S}$ \\
\hline Neomycin & 30 & 0 & $\mathrm{R}$ \\
\hline Doxycycline & 30 & 30 & $\mathrm{~S}$ \\
\hline Nalidixic acid & 30 & 33 & $\mathrm{~S}$ \\
\hline Tetracycline & 30 & 23 & $\mathrm{~S}$ \\
\hline Trimethoprim & 1.25 & 30 & $\mathrm{~S}$ \\
\hline
\end{tabular}




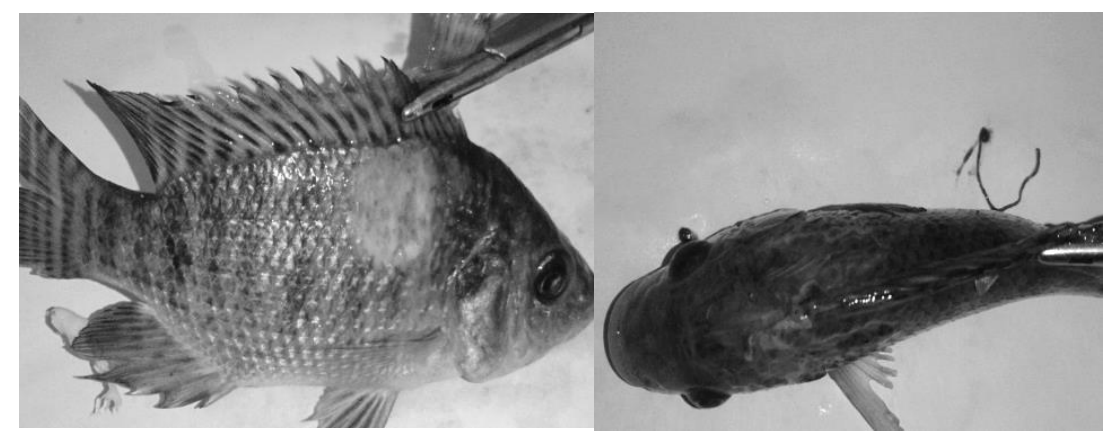

Figure (1): $O$. niloticus showed white necrotic tissue, rough scales and scale less area behind the head.

Figure (2): $O$. niloticus showed erosion \&ulcer of the back reached to the muscle (saddle back appearance)

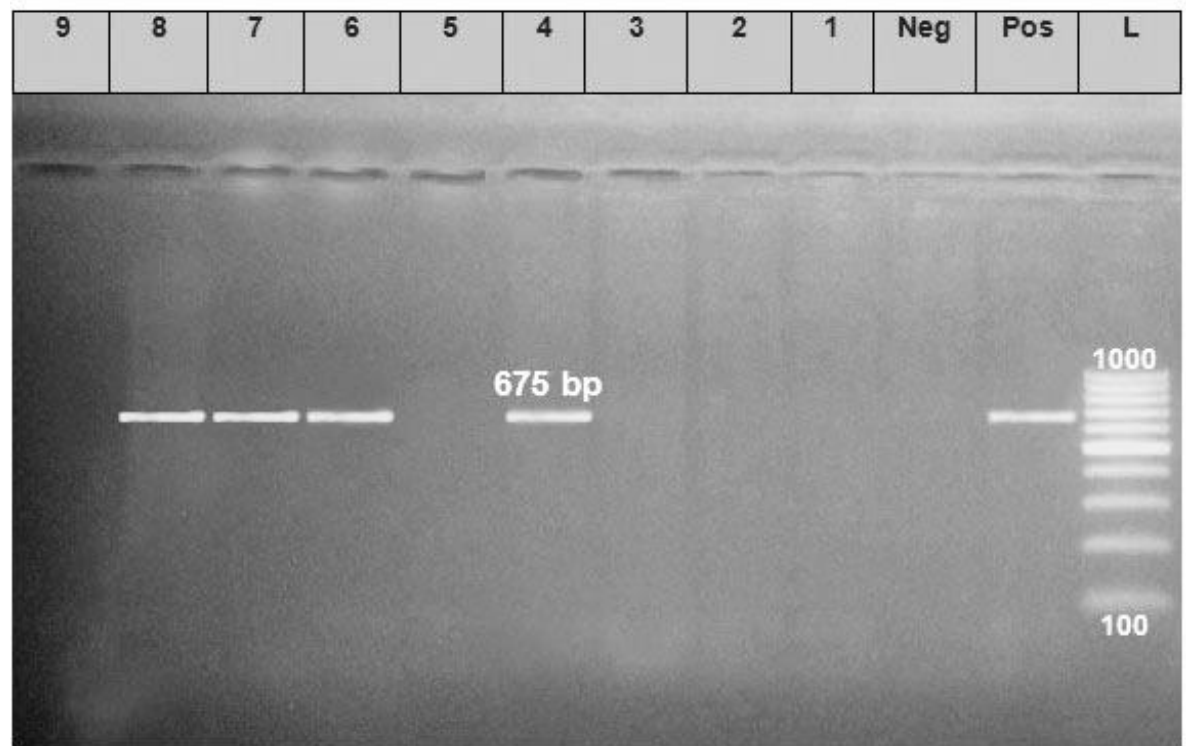

Figure (3): Electrophortic pattern of 16S r RNA PCR assay of $F$. columnare isolated from fish.

L=ladder

Pos=positive control

$\mathrm{Neg}=$ Negative control (saline)

Sample: F. columnare isolates from Oreochromis niloticus (lanes: 4, 6, 7, 8).

Refrences:

Bauer, A.W., Kirby, W.M., Sherris, J.C., and Turck, M., (1966): "Antibiotic susceptibility testing by a standardized single disk method". Am. J. Clin. Pathol. 45. 493-496. 1966.

Bullock, G. L., Hsu, T. C., \& Shotts Jr, E. B. (1986); Columnaris disease of fishes. 
Collins,C.H; Lyne,P.M and Grange,J.M. (1989); Collins and Lyne Microbiology Methods 6th Ed. Butter worth Heineman Oxford, London, PP. 93.

Darwish, A. M., Ismaiel, A. A., Newton, J. C., \& Tang, J. (2004); Identification of Flavobacterium columnare by a species-specific polymerase chain reaction and renaming of ATCC43622 strain to Flavobacterium johnsoniae. Molecular and Cellular Probes, 18(6), 421-427.

Durborow, R. M., Thune, R. L., Hawke, J. P., \& Camus, A. C. (1998); Columnaris disease: a bacterial infection caused by Flavobacterium

columnare. Southern Regional Aquaculture Centre Publication, (479).

Elgamal, R.M.A(1995); Bacterial Causes of Fin rot in Some Freshwater fishes.M.V.SC. Thesis (Bacteriology, Immunology and mycology) Suez Canal Univ.

Eltalawy (2008); Flavobacterial infection in African shaptooth catfish Claris garpienus M.V.Sc.Thesis, faculty of Vet.Med. Assiut univ.

Griffin, B. R. (1992); A simple procedure for identification of Cytophaga columnaris. Journal of Aquatic Animal Health, 4(1), 63-66. Hesami, S., Parkman, J., MacInnes, J. I., Gray, J. T., Gyles, C. L., \& Lumsden, J. S. (2010); Antimicrobial susceptibility of Flavobacterium psychrophilum isolates from Ontario. Journal of Aquatic Animal Health, 22(1), 39-49.

Kamel,A.M(2013);

Flavobacteriosis in oreochromis niloticus .M.V.SC. Thesis, Fac.Vet.MED.,Beni-suef Univ.

NCCLS/CLSI

(National

Committee for Clinical

Laboratory Standards/Clinical and Laboratory Standards Institute), (2007): CLSI document GP 18- Laboratory design; approved guideline. $2^{\text {nd }}$ ed. Clinical and Laboratory Standards Institute, Wayne (PA); 2007.

Sambrook, J.; Fritscgh, E.F. and Mentiates (1989); Molecular coloning. A laboratory manual. Vol 1., Cold spring Harbor Laboratotry press, New York.

Smith,P.D.(1982); Analysis of hyperosmotic and bath methods for fish vaccination :Comparison of uptake of particulate and nonparticulate antigens .Developmental and comparative Immunology 2:2333-238.

United States Department of Agriculture.( 2003); Reference of 2002 U. S. catfish health and production practices. Center for Epidemiology and Animal Health, Fort Collins, Colorado. p. 64-67.

Varga, Z., Sellyei, B., Paulus, P., Papp, M., Molnár, K., \& Székely, C. (2016); Isolation and characterisation of flavobacteria from wild and cultured freshwater fish species in Hungary. Acta Veterinaria Hungarica, 64(1), 1325. 


\section{دراسات بكتريولوجية علي الفلافوباكتريم كولمنار في الأسماك}

حمة ابراهيم عيد, * محمدالسيدابوالعطا* *,ندا حسين عيداروس*, نجوي ابراهيم فرج الله

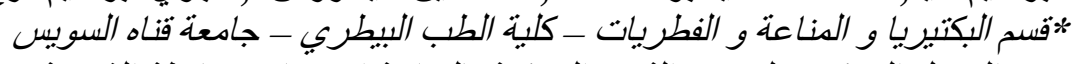
*** المعدل المركزي لبحوث الثروة السمكية بالعباسة,/بوحماد, محافظة الثرقبية

جُمعت . ․ سمكة (بلطي نيلي) عشوائياً من المزارع التابعة للمعمل المركزي لبحوث الثروة

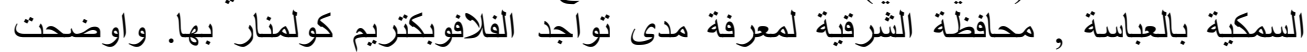

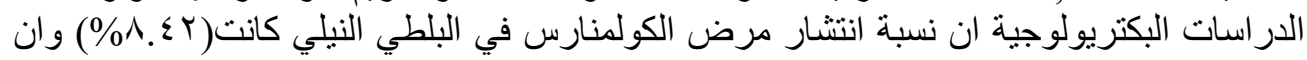

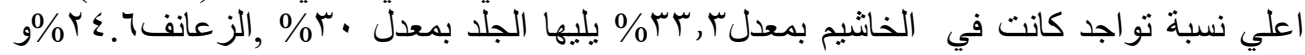

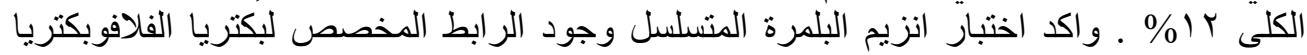
كولمنار في سمك البلطي النيلي وذلك عند

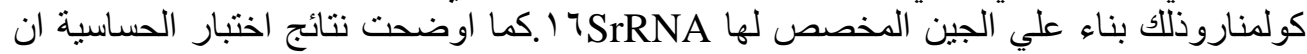

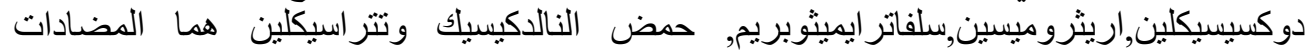

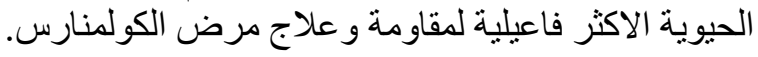

